J. Clin. Chem. Clin. Biochem.

Vol. 24, 1986, pp. $451-455$

(C) 1986 Walter de Gruyter \& Co. Berlin - New York

\title{
Determination of Circulating Monomeric Katacalcin and Calcitonin: Physiological Studies in Normal Subjects ${ }^{1}$ )
}

\author{
By W. Woloszczuk
}

Ludwig Boltzmann Institut für Klinische Endokrinologie

H. Schuh

Ludwig Boltzmann Institut für Altersforschung and

\section{J. Kovarik}

II. Medizinische Universitätsklinik

Wien, Austria

(Received November 11, 1985/February 14, 1986)

Summary: Katacalcin is a recently discovered peptide, contained within the calcitonin precursor. For the highly sensitive readioimmunological measurement of katacalcin and calcitonin we used extraction on C-18, thereby lowering the detection limits in serum to $0.8 \mathrm{pmol} / 1$ (katacalcin) and $0.7 \mathrm{pmol} / 1$ (calcitonin), and simultaneously improving the specificities of both assays for the monomeric forms of the peptides. Extraction recoveries were $>96 \%$ and $>95 \%$ for pure monoiodinated $\left.{ }^{125} \mathrm{I}\right] \mathrm{Ty} \mathrm{r}(0)$-katacalcin and [ $\left.{ }^{125} \mathrm{I}\right]$ calcitonin, respectively; and $95-98 \%$ and $91-97 \%$ respectively for the corresponding unlabelled peptides. This method is sufficiently sensitive and specific for studies on the physiology of both peptides. Gel filtration of serum from a patient with medullary carcinoma of the thyroid showed that the majority of high molecular weight forms of katacalcin and calcitonin did not bind to $\mathrm{C}-18$, and that the eluted material consisted to more than $90 \%$ of monomeric katacalcin and calcitonin. Basal levels (mean \pm SEM) of katacalcin were higher in men $(3.0 \pm 0.6 \mathrm{pmol} / \mathrm{l}$, age $<40$ years, and $1.8 \pm 0.4 \mathrm{pmol} / \mathrm{l}$, age $>40$ years $)$ and younger women $(2.1 \pm 0.4$ $\mathrm{pmol} / \mathrm{l})$ than in older women $(1.3 \pm 0.6 \mathrm{pmol} / \mathrm{l} ; \mathrm{p}<0.02)$. The respective values for calcitonin were $5.1 \pm 0.9$ and $4.0 \pm 0.6 \mathrm{pmọl} / 1$ for young and older men, and $2.3 \pm 0.4$ und $2.8 \pm 0.8 \mathrm{pmol} / 1$ for young and older women, with a significant sèx-related difference in both age groups. Basal serum levels of katacalcin and calcitonin were highly correlated (katacalcin $=0.66$ calcitonin $-0.12 \mathrm{pmol} / \mathrm{l} ; \mathrm{p}<0.001$ ). Calcium infusions ( $2 \mathrm{mg} / \mathrm{kg}$ body weight) in 30 normal subjects showed a significantly lower secretory capacity for katacalcin and calcitonin in older women, but no correlation between basal level and peak levels after five minutes. The peptides were undetectable in 5 (katacalcin) and 4 (calcitonin) out of 11 athyroid patients, and they were higher in patients on haemodialysis.

\section{Bestimmung von zirkulierendem monomeren Katakalcin und Calcitonin}

Zusammenfassung: Katakalcin ist ein kürzlich entdecktes Peptid, das Teil der Calcitonin-Vorstufe ist. Wir haben eine C-18 Extraktionsmethode entwickelt, mit der Katakalcin und Calcitonin aus biologischen Proben angereichert und danach mit hoher Spezifität und Sensitivität $(0,8 \mathrm{pmol} / 1$ für Katakalcin und $0,7 \mathrm{pmol} / 1$ für Calcitonin) radioimmunologisch bestimmt werden können. Die Wiederfindungsraten von reinem monoiodier-

1) Supported by the Lorenz Böhler Stiftung. 
tem $\left[{ }^{125} \mathrm{I}\right] \operatorname{Tyr}(0)$-Katakalcin und $\left[{ }^{125} \mathrm{I}\right]$ Calcitonin waren $>96 \%$ und $>95 \%$, bzw. $95-98 \%$ und $91-97 \%$ für die unmarkierten Peptide. Diese Methodik erwies sich als ausreichend empfindlich und spezifisch für Studien zur Physiologie der beiden Peptide. Gelfiltration von Serum eines Patienten mit medullärem Schilddrüsenkarzinom zeigte, daß der Großteil der Katakalcin- und Calcitonin-Fraktionen mit hohem Molekulargewicht nicht an C-18 bindet und daß das eluierte Material zu mehr als $90 \%$ aus monomerem Katakalcin und Calcitonin besteht. Basale Konzentrationen (Mittel \pm SEM) von Männern $(3,0 \pm 0,6 \mathrm{pmol} / 1$, Alter $<40$ Jahre, und 1,8 $\pm 0,4 \mathrm{pmol} / \mathrm{l}$, Alter $>40 \mathrm{Jahre})$ und jungen Frauen $(2,1 \pm 0,4 \mathrm{pmol} / \mathrm{l})$ waren höher als von älteren Frauen $(1,3 \pm 0,6 \mathrm{pmol} / \mathrm{l} ; \mathrm{p}<0,02)$. Die entsprechenden Calcitonin-Werte betrugen für Frauen $2,3 \pm 0,4$ und 2,8 $\pm 0,8 \mathrm{pmol} / \mathrm{l}$, und für Männer 5,1 $\pm 0,9$ bzw. 4,0 $\pm 0,6 \mathrm{pmol} / \mathrm{l}$, mit einem geschlechtsabhängigen Unterschied in beiden Altersgruppen. Basale Katakalcin- und Calcitonin-Konzentrationen korrelierten signifikant (Katakalcin $=0,66$ Calcitonin $-0,12 \mathrm{pmol} / \mathrm{l} ; \mathrm{p}<0,001)$. Calciuminfusionen $(2 \mathrm{mg} / \mathrm{kg} \mathrm{Körperge-}$ wicht) in 30 Normalpersonen ergaben eine signifikant niedrigere Sekretionsreserve für Katakalcin und Calcitonin in älteren Frauen, es bestand aber keine Korrelation zwischen basalen und stimulierten Werten. Katakalcin und Calcitonin waren in 5 bzw. 4 von 11 athyreoten Patienten nicht nachweisbar und bei hämodialysierten Patienten erhöht.

\section{Introduction}

Calcitonin is a small peptide hormone synthesized and secreted mainly by the C-cells of the thyroid. As for many other secretory peptides, the first translation product is a larger precursor peptide, whose amino acid sequence was deduced from analysis of the cDNA of the calcitonin gene $(1,2)$. Human calcitonin resides towards the $\mathrm{C}$-terminal end of this precursor and is flanked on its C-terminal side by a 21 amino acid peptide named PDN-21 (3) or katacalcin (4). At present, it is uncertain whether synthetic katacalcin has biological activity similar to that of calcitonin (5), which is so far the only hormone known to lower serum calcium concentration. Although regulated by fluctuations of serum calcium in the physiological range (6), the physiological significance of calcitonin is still unclear and the influence of katacalcin has not yet been studied in detail. The continuing controversies about basal and stimulated values, sex- and age-dependence and diurnal variations are complicated by the technical difficulties of assaying calcitonin in biological fluids. One of the causes for the discrepant results reported in the literature (7) seems to be the marked immunoheterogeneity of glandular $(8)$ and circulating $(9,10)$ human calcitonin. While most antisera were raised against synthetic monomeric calcitonin, they nevertheless crossreact with other forms of circulating calcitonin. Similar effects have been described for other peptide hormones, but no data on the heterogeneity of katacalcin have been reported. Recently, simple extraction methods were described that allow the determination of monomeric calcitonin, the major biologically active form of calcitonin (11). A similar approach was also reported for katacalcin (4). Since few data are available on normal levels of katacalcin and their relation to calcitonin, we have developed a procedure that allows the simultaneous extraction, purification and concentration of calcitonin and katacalcin from small biological specimens before radioimmunoassay, and we have applied this method to physiological studies of calcitonin and katacalcin.

\section{Materials and Methods}

Disposable C-18 SEP-PAK cartridges (Waters Associates Inc., Milford, MA) were wetted with $2 \mathrm{ml}$ methanol and washed with $3 \mathrm{ml}$ water/methanol/trifluoroacetic acid $(95 / 5 / 0.1$, by vol.). Three ml plasma were acidified with $1 \mathrm{ml} 1 \mathrm{~mol} / 1 \mathrm{HCl}$ and fed by gravity slowly through each cartridge, followed by three washes with $1 \mathrm{ml}$ water/methanol/trifluoroacetic acid (95/ $5 / 0.1$, by vol.) each. Adsorbed katacalcin was quantitatively eluted with $3 \mathrm{ml}$ water/acetone/trifluoroacetic acid (75/25/0.1, by vol.) and calcitonin with $3 \mathrm{ml}$ water/acetone/trifluoroacetic acid (55/45/0.1, by vol.). For routine purposes both peptides were eluted simultaneously with $4 \mathrm{ml}$ water/acetone/trifluoroacetic acid (55/45/0.1, by vol.). The eluates were partially evaporated at $37^{\circ} \mathrm{C}$ under a stream of nitrogen, frozen and lyophilized. On the day of the assay, the lyophilised residues were dissolved in $0.6 \mathrm{ml}$ RIA buffer $(20 \mathrm{mmol} / 1$ Tris $/ \mathrm{HCl}$, $\mathrm{pH} 8.5,10 \mathrm{~g} / \mathrm{l}$ bovine serum albumin, $0.2 \mathrm{~g} / 1 \mathrm{NaN}_{3}$ and $0.3 \mathrm{ml} / 1$ Tween 20). Katacalcin and calcitonin were determined in 24 hour/24 hour non-equilibrium radioimmunoassays in a total volume of $300 \mu \mathrm{l}$ with incubation at $4^{\circ} \mathrm{C}$. Antisera (Cambridge Research Biochemicals, Harston, UK) were used in half the recommended quantity. Synthetic peptides (Peninsula Laboratories Inc., Belmont, CA) were used as standards and as starting material for the tracers, which were prepared from $\operatorname{Ty} r(0)$ katacalcin and calcitonin by the iodogen method and purified by chromatofocussing (12). Approx. 10000 counts/min of pure monoiodinated peptide were added per tube. Separation was achieved by addition of a preprecipitated second antibody (Sorin Biomedica, Saluggia, Italy). Standard curves were run in triplicate, and usually two sample dilutions were assayed to check for parallelism. Standard curves were evaluated using a linear least squares fit of logit/log transformed data. Sensitivity of an assay was defined as $\mathrm{B}_{0}-3 \mathrm{SD}$ and, disregarding assay runs with $\mathrm{SD}>2.5 \%$ was set at $\mathrm{B} / \mathrm{B}_{\circ} 0.925$. Radioactive recoveries were determined by subtracting from the total activity the percentages eluted during application and washing steps and retained on the cartridge after elution. Gel filtration on Sephadex G-50 superfine was carried out as previously described (8).

Results are expressed as the mean \pm SEM if not stated otherwise. For comparison of groups, the non-parametric rankcorrelation coefficient was used. 
Subjects and study protocol

Specimens were obtained from normal volunteers not having any noticeable disease and not receiving any medication known to interfere with calcium metabolism. All samples were taken and all studies performed in the morning after an overnight fast. Samples for serum were collected in glass tubes and stored at $4^{\circ} \mathrm{C}$ for one to three hours, then centrifuged. In some cases EDTA- and heparin-plasma were obtained at the same time. All samples were kept frozen at $-20^{\circ} \mathrm{C}$ for not longer than 2 months before extraction and assay.

Basal samples were obtained from 11 athyroid patients, 26 patients on haemodialysis and 90 healthy individuals (47 men and 43 women). Four groups were compared: 23 young men (18-39 years), 30 young women (19-39 years), 24 older men (40-63 years) and 13 older women ( $40-76$ years).

For chromatographic separation of immunoreactive peptides, the serum of a patient with a medullary carcinoma of the thyroid was used.

For the calcium loading test, Ca-gluconate ( $8.5 \%$ solution) was infused $i$. v. for one minute at a dose of $2 \mathrm{mg} / \mathrm{kg}$ body weight and blood was withdrawn at 0,5 and 10 minutes. Four groups: 9 young men ( $19-38$ years), 8 young women (19-36 years), 6 older men ( $42-63$ years) and 9 older women $(40-69$ years) underwent this test.

\section{Results}

\section{Validation of the analytical method}

The recovery of monoiodinated peptides was checked with several normal sera and plasmas and with samples from patients on haemodialysis; recovery was consistently higher than $96 \%$ for $\operatorname{Tyr}(0)$-katacalcin (98 $\pm 1 \%, n=12$ ), and higher than $95 \%$ for calcitonin $(97 \pm 2 \%, n=11)$. Recoveries for unlabelled peptides were similarly high in the case of katacalcin (median 96\%, range 95-98\%) and only slightly lower for calcitonin (median 93\%, range $91-97 \%$ ). In view of the consistently high recovery, results are given without correction. There were no differences between results obtained in serum or plasma samples (EDTA or heparin) from the same subjects. Storage at $-20^{\circ} \mathrm{C}$ for up to two months did not affect the results of either assay. The sensitivities of the assays varied less than $30 \%$ and were at least $0.8 \mathrm{pmol} / 1$ for katacalcin-and $0.7 \mathrm{pmol} / 1$ for calcitonin. The coefficients of variation (between assay) in the useful range of the test $\left(B / B_{0} \cdot 0.85-0.15\right)$ were not greater than $14 \%$.

The gel filtration profiles of a serum before (katacalcin $10.5 \mathrm{nmol} / 1$, calcitonin $17.3 \mathrm{nmol} / \mathrm{l}$ ) and after C18 extraction (katacalcin $1.77 \mathrm{nmol} / \mathrm{l}$, calcitonin 2.12 $\mathrm{nmol} / \mathrm{l}$ ) and of the eluate are shown in figure 1. Most of the katacalcin- and calcitonin-immunoreactivity of large molecular weight was not adsorbed and was recovered in the flow-through, whereas monomeric peptides were retained and could be eluted.
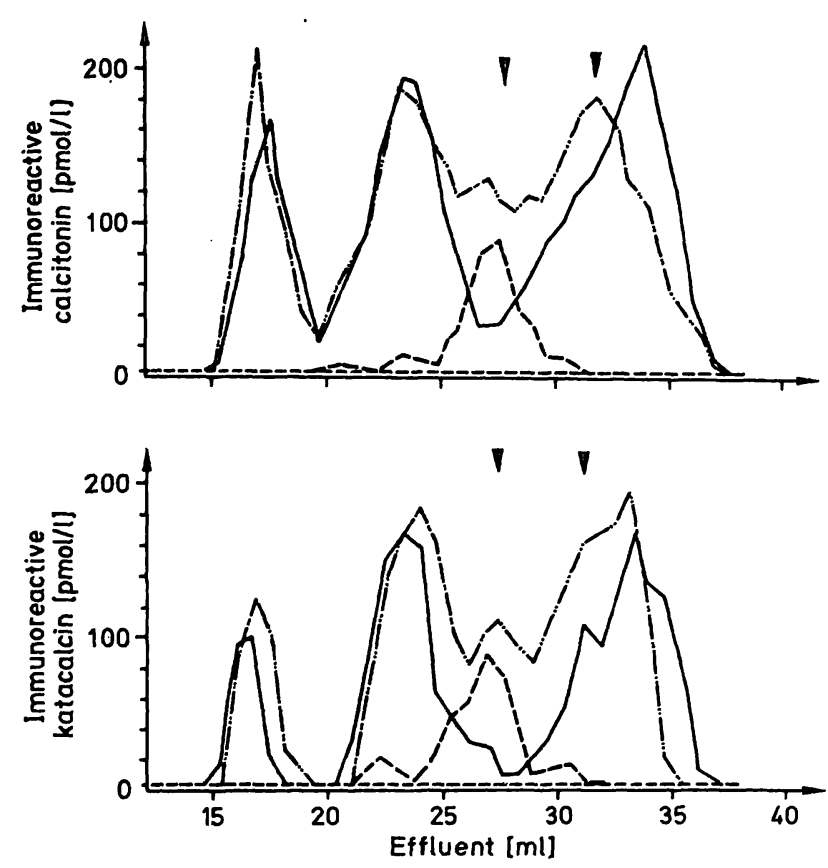

Fig. 1. Gel filtration profiles of immunoreactive calcitonin and katacalcin before $(-\cdots-\cdots-)$ and after $(-)$ extraction by a $\mathrm{C}-18$ cartridge and in the eluate $(----)$ from the cartridge. $0.2 \mathrm{ml}$ of serum from a patient with a medullary carcinoma of the thyroid, or the equivalent volumes of acidified flow through from the C-18 cartridge, or of lyophilized and reconstituted eluate were chromatographed. The vertical arrows represent, from the left to the right, the elution positions of $\left[{ }^{125} \mathrm{I}\right] \mathrm{calci}$ tonin and $\left[{ }^{3} \mathrm{H}\right]$ leucine. The dashed lines indicate the detection limits of the radioimmunoassays.

Basal levels and effect of calcium infusions

Basal katacalcin and calcitonin serum levels (tab. 1) were highly correlated: katacalcin $=0.66$ calcitonin $-0.12 \mathrm{pmol} / 1(\mathrm{r}=0.82 ; \mathrm{p}<0.001$; fig. 2$)$.

The rise in katacalcin and calcitonin levels after infusion of calcium in each of the four groups is shown in figure 3. Although peak levels for katacalcin and calcitonin were lower for older subjects, no significant age-dependence was seen.

Tab. 1. Basal serum levels of katacalcin and calcitonin.

\begin{tabular}{lllll}
\hline $\begin{array}{l}\text { Age range } \\
\text { (years) }\end{array}$ & $\mathrm{N}$ & $\begin{array}{l}\text { Kata- } \\
\text { calcin } \\
\text { (pmol/l) }\end{array}$ & $\begin{array}{l}\text { Calcitonin } \\
\text { (pmol/l) }\end{array}$ \\
\hline $18-39$ & men & 23 & $3.0 \pm 0.6$ & $5.1 \pm 0.9$ \\
$19-39$ & women & 30 & $1.8 \pm 0.4$ & $4.0 \pm 0.6(\mathrm{a})$ \\
$40-36$ & men & 24 & $2.1 \pm 0.4$ & $2.3 \pm 0.4$ \\
$40-76$ & women & 13 & $1.3 \pm 0.6(\mathrm{~b})$ & $2.8 \pm 0.8(\mathrm{c})$ \\
\hline
\end{tabular}

Difference between men and women:

a) $\mathrm{p}<0.01$

b) $\mathrm{p}<0.02$

c) $\mathrm{p}<0.05$ 


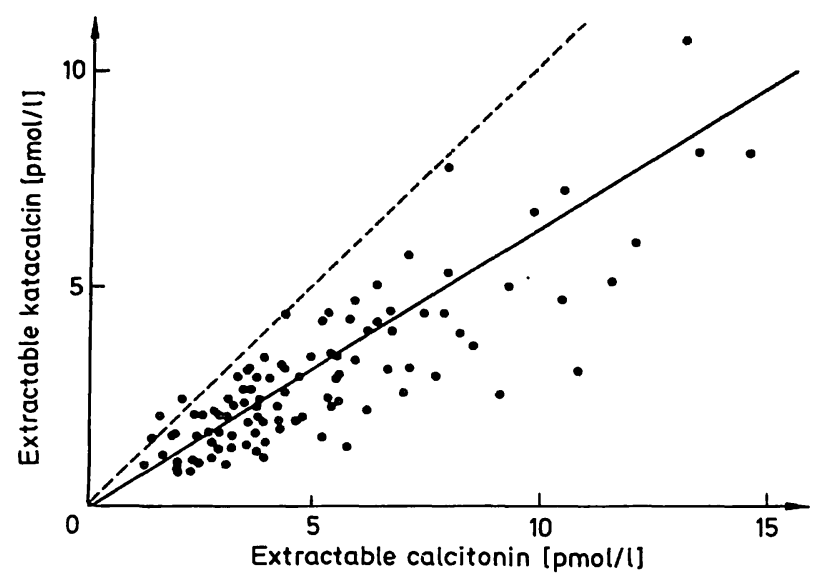

Fig. 2. Serum levels of extractable katacalcin and calcitonin. The solid line indicates the regression line fitted by the method of least squares. The dashed line indicates the line of equimolarity.
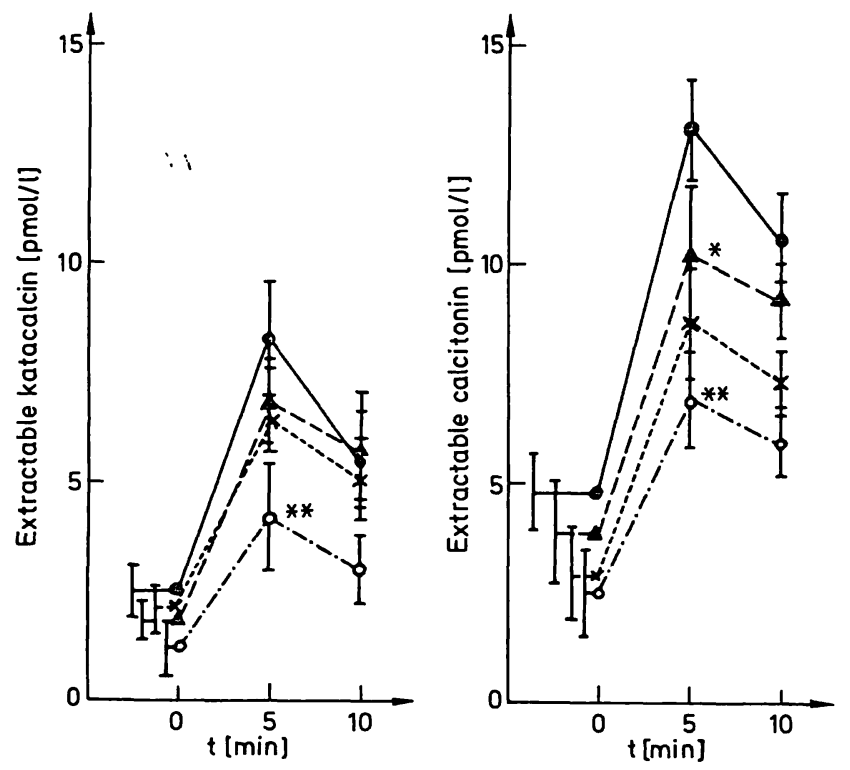

Fig. 3. Serum levels of extractable katacalcin and calcitonin before and after stimulation by calcium infusion in normal volunteers.

$$
\begin{aligned}
& \text { males: } \rightarrow<40 \text { years } \\
& 4--->40 \text { years } \\
& \text { females: } x \text {-.------- }<40 \text { years } \\
& 0-\cdot-.>40 \text { years }
\end{aligned}
$$

Differences between men and women (in the respective age groups):

*) $\mathrm{p}<0.02$

**) $\mathrm{p}<0.05$

\section{Pathological levels}

Katacalcin was undetectable $(<0.8 \mathrm{pmol} / \mathrm{l})$ in 5 out of 11 athyroid patients, the others had levels between 0.8 and $2.9 \mathrm{pmol} / \mathrm{l}$. Calcitonin levels were up to 4.8 $\mathrm{pmol} / \mathrm{l}$ and undetectable in 4 subjects $(<0.7 \mathrm{pmol} / \mathrm{l})$. In 26 patients on chronic intermittent haemodialysis, levels of katacalcin were elevated compared to an age- and sex-matched control group $(p<0.01)$, and ranged from 4.1 to $30.8 \mathrm{pmol} / \mathrm{l}$. Calcitonin levels were between 5.1 and $39.7 \mathrm{pmol} / 1$, also significantly higher than the control collective $(\mathrm{p}<0.02)$.

\section{Discussion}

We report here a simple method for the extraction and simultaneous purification of katacalcin and calcitonin from serum or plasma samples using $\mathrm{C}-18$ silica as adsorbent material, with a reasonable requirement of sample volume $(3 \mathrm{ml})$. Compared with the extraction on silica gel as described for calcitonin (11), this method gives better recoveries and highly reproducible extraction characteristics, allowing the separation of katacalcin and calcitonin. Much broader and therefore overlapping elution profiles were found with silica gel (results not shown). With C-18, similarly high extraction yields have been obtained with other peptide hormones, such as endorphins (13) or human atrial natriuretic peptide (14). Although few data are published, the direct determination of katacalcin seems to suffer from the same limitation as the determination of calcitonin and other peptides in biological samples (4), requiring extraction and concentration steps (15). For calcitonin, improvements of assay performance, most notably the removal of variations due to nonspecific factors, has resulted in an established upper normal limit of approximately $30 \mathrm{pmol} / 1$. Extraction procedures have lowered this limit to $6 \mathrm{pmol} / \mathrm{l}(11,7)$. One publication reported equimolar concentrations of katacalcin and calcitonin in the serum of normals and patients with medullary carcinoma of the thyroid. Although we found the concentrations of katacalcin and calcitonin to be highly correlated, calcitonin levels were not equimolar (7), but about 50\% higher than katacalcin levels, and individual values did deviate noticeably from the line of correlation. Since the extraction and the assay procedure appear to be free from interferences that might explain this deviation, we conclude that excretion and metabolism of the two peptides must be sufficiently variable to account for the observed differences. In contrast, the general trends were practically identical, although the sex-related difference of basal katacalcin values was not statistically significant in younger females. Lower basal levels of both katacalcin and calcitonin were seen in older women. Since the relative deficiency of calcitonin may predispose to bone los̀s and katacalcin might influence calcium metabolism, it is necessary to critically examine the relation of monomeric calcitonin and katacalcin deficiency to long term skeletal homeostasis. Since monomeric calcitonin is the main biologically active fraction of immunoreactive calcitonin (16), a similar relation might hold true for katacalcin and thus make the measurements of extracted, purified katacalcin more reliable clinically. Changes in calcitonin and katacalcin levels after calcium stimulation have been shówn for women before 
and after ovarectomy, using the same assay procedure (17). Several groups have reported that the increase of calcitonin secretion after calcium infusion decreases with age. Amongst our normal individuals, only the older females had significantly reduced peak values of both katacalcin and calcitonin. However, it is very difficult to compare these results with published data, since different protocols have been used that may influence the results (18). In addition, there seem to be large ethnic differences in the secretory capacity of katacalcin and calcitonin, which might explain reported discrepancies (15). The present data confirm the sex-related difference of calcitonin levels and extend this observation to katacalcin levels, measuring the concentrations of only the monomeric form of this peptide. Techniques similar to ours should enable physiological studies on age- and sexrelated bone loss.

\section{Acknowledgement}

We are indebted to Mrs. T. Kössler and Ing. M. Horzemsky for their excellent technical assistance.

\section{References}

1. Birnbaum, R.S., O'Neil, J. A., Muszynski, M., Aron, D. C. \& Roos, B. A. (1982) J. Biol. Chem. 257, $241-244$.

2. Craig, R. K., Hall, L., Edbrooke, M. R., Allison, J. \& MacIntyre, I. (1982) Nature 295, 245-247.

3. Macintyre, I., Hillyard, C. J., Murphy, P. K., Reynolds, J. J., Gaines Das, R. E. \& Craig, R. K. (1982) Nature 300, $460-462$.

4. Hillyard, C. J., Abeyasekera, G., Craig, R. K., Myers, C., Stevenson, J. C. \& MacIntyre, I. (1983) Lancet I, 846-848.

5. Maclntyre, I., Hillyard, C. J., Reynolds, J. J., Gaines Das, R. E. \& Craig, R. K. (1984) Nature 308, 85.

6. Austin, L. A., Heath, H. III. \& Go, V. L. W. (1979) J. Clin. Invest. $64,1721-1724$.

7. Heath, H. III., Body, J. J. \& Fox, J. (1984) Biomed. Pharmacotherapy $38,241-245$.

8. Woloszczuk, W. \& Kovarik; J. (1981) Hormone Metab. Res. $13,460-463$.

9. Dermody, W. C., Rosen, M.A., Anathawamy, R., McCormic, W. M. \& Levy, A. G. (1981) J. Clin. Endocrinol. Metab. 52, 1090-1098.

10. Goltzman, D. \& Tischler, A. S. (1979) J. Clin. Invest. 61, $449-456$

11. Body, J. J. \& Heath, H. III. (1983) J. Clin. Endocrinol. Metab. 57, 897-903.

12. Woloszczuk, W. (1986) J. Immunol. Meth. (in press).

13. Angwin, P. \& Barchas, J. D. (1982) J. Chromatography $231,173-177$.

14. Hartter, E., Woloszczuk, W. \& Stummvoll, H.-K. (1986) Clin. Chem. 32, $441-445$.

15. Stevenson, J. C., Myers, C. H. \& Adjukiewicz, A. B. (1984) Calcif. Tissue. Int. 36, 725-728.

16. Tobler, P. H., Jöhl, A., Born, W., Maier, R. \& Fischer, J. A. (1982) Biochim. Biophys. Acta 707, 59-65.

17. Marton, I. S., Jancsy, G. \& Woloszczuk, W. (1985) Exp. Clin. Endocrinol. 86, $361-364$.

18. MacIntyre, I., Girgis, S. I. \& Hillyard, C. J. (1984) Biomed. Pharmacotherapy $38,230-234$.

\section{W. Woloszczuk}

Ludwig Boltzmann Institut für Klinische Endokrinologie 2. Medizinische Universitätsklinik Garnisongasse 13

A-1090 Wien 
